\section{The analysis of attitudes of pre-service teachers who will provide environmental education in elementary and secondary scholls towards solid wastes and recycling in terms of various variables}

İlkokul ve ortaokullarda çevre eğitimi verecek olan öğretmen adaylarının katı atıklar ve geri dönüşüme yönelik tutumlarının farklı değişkenler açısından incelenmesi

\author{
Mustafa Kışoğlu ${ }^{1}$ \\ Tahsin Yildırım ${ }^{2}$
}

\begin{abstract}
The purpose of this study is to analyse the attitudes of prospective science, elementary school and social sciences teachers who will provide environmental education in elementary and secondary schools in the future towards solid wastes and recycling in terms of various variables. The sample of the study consists of 149 preservice teachers who are receiving education at the education faculty of a university located in Middle Anatolia Region in Turkey. "Scale of Pre-service Teachers' Attitudes towards Solid Wastes and Recycling", which was developed by Karatekin (2013) and which consists of three dimensions and 33 items was used in this study which was conducted by screening model. As a result of the study, it was revealed that pre-service teachers generally have a positive attitude towards solid wastes and recycling. Besides, there is a difference among the pre-service teachers' attitudes in all three dimensions of the scale with regard to gender and department. Also, the scores of preservice teachers for the initiative and participation
\end{abstract}

Özet

Yapılan bu araştırmanın amacı öğretmen olduklarında ilkokul ve ortaokullarda çevre eğitimi verecek olan fen bilgisi, sinif ve sosyal bilgiler öğretmen adaylarının katı atıklar ve geri dönüşüme yönelik tutumlarının farklı değişkenler açısından incelenmesidir. Araştırmanın örneklemini Türkiye'nin İç Anadolu Bölgesinde bulunan bir üniversitenin eğitim fakültesinde öğrenim gören 149 öğretmen adayı oluşturmaktadır. Tarama modelinde gerçekleştirilen araştırmada veri toplama arac1 olarak Karatekin (2013) tarafindan geliştirilen, üç alt boyutlu ve toplam 33 sorudan oluşan "Öğretmen Adayları İçin Katı Atık ve Geri Dönüşüme Yönelik Tutum Ölçeği” kullanılmıştır. Araştırma sonucunda öğretmen adaylarının katı atıklar ve geri dönüşüme yönelik tutumlarının genel olarak olumlu olduğu sonucuna ulaşılmıştır. Bununla birlikte öğretmen adaylarının tutum ölçeğinin üç alt boyutunda da tutumları arasında cinsiyetlerine ve anabilim dallarına göre farklık bulunmaktadır. Ayrıca öğretmen adaylarının tutum ölçeğinin girişim ve katılım ile ilgi ve duyarlılık alt

${ }^{1}$ Yrd. Doç. Dr., Aksaray Üniversitesi, Eğitim Fakültesi, Fen Bilgisi Eğitimi Anabilim Dalı, mkisoglu@,hotmail.com

${ }^{2}$ Yrd. Doç. Dr., Aksaray Üniversitesi, Eğitim Fakültesi, Sosyal Bilgiler Eğitimi Anabilim Dalı, tahsinyildirim@msn.com 
Kışoğlu, M. ve Yıldırım, T. (2015). İlkokul ve ortaokullarda çevre eğitimi verecek olan öğretmen adaylarının katı atıklar ve geri dönüşüme yönelik tutumlarının farklı değişkenler açısından incelenmesi. International Journal of Human Sciences, 12(1), 1518-1536. doi: $10.14687 /$ ijhs.v12i1.3283

and interest and sensitivity dimensions of the scale vary depending on their behaviours of separating the wastes and throwing them into the related recycle bin and preferring products that are suitable for recycling. It was found out that there is no difference among the participants' scores of attitudes towards solid wastes and recycling in terms of settlement, level of income, educational level of the parents and membership to environmental associations.

Keywords: Environmental education, solid waste, recycling, attitude, pre-service teacher

(Extended English abstract is at the end of this document) boyutu puanları adayların atıkları ayrıştırarak ilgili geri dönüşüm kutusuna atma ve geri dönüşüme uygun ürünleri tercih etme davranışlarına göre farklılaşmaktadır. Araştırmaya katılan öğretmen adaylarının katı atıklar ve geri dönüşüme yönelik tutum ölçeği alt boyutu puanları arasında adayların yerleşim birimi, gelir düzeyi, ebeveynlerinin eğitim durumu ve çevre kuruluşuna üyelik durumları bakımından herhangi bir farklıllğın olmadığı belirlenmiştir.

Anahtar Kelimeler: Çevre eğitimi, katı atık, geri dönüşüm, tutum, öğretmen aday1

\section{Giriş}

Çevresel bozulmanın en önemli özelliklerinden bir tanesi küresel ölçekte tüm insanlığ1 etkileyen bir sorun olmasıdır (Khan, 2013). Doğal kaynakların azalması, su kirliliği, hava kirliliği, küresel ısınma, ozon tabakasının incelmesi, biyoçeşitliliğin azalması, toprak kirliliği gibi sorunlar bugün insanlığın karşı karşıya olduğu küresel ölçekteki çevre sorunlarından bazılarıdır (Anand, 2013). Son yıllarda önemli bir problem haline gelen ve insanlığın geleceğini tehdit eden çevre sorunlarından bir tanesi de katı atık sorunudur.

"İnsanların sosyal ve ekonomik faaliyetleri sonucunda işe yaramaz hale gelen ve akıc1 olabilecek kadar sıvı içermeyen her tür madde ve malzemeyi katı atık olarak tanımlamak mümkündür.” (MEB, 2009, s.11). Kat1 atıklar evsel, tıbbi, endüstriyel ve zirai kaynaklı insan faaliyetleri sonucunda meydana gelen ve insan sağllğını tehdit eden çevre kirleticileridir (Kimani, 2007). Artan nüfus, gelişen ekonomi ve yükselen yaşam standartlarıyla birlikte fazlalaşan üretim ve tüketim faaliyetleri, bu faaliyetler neticesinde açığa çıkan katı atık miktarını artırmıştır (Minghua et al., 2009; Mutlu, 2013). Bunun sonucunda özellikle nüfusun fazla olduğu bölgelerde insanların tüketimine sunulan ürünlerin atık olarak ortaya çıkması günümüzde önemli bir sorun haline gelmiştir (Koçer ve Işık, 2005). Çünkü katı atıklar uzun süre bozulmadan doğada kalarak çevreyi kirletmekte ve insan sağlığını olumsuz yönde etkilemektedir (Kayranlı v.d., 2003 akt. Çimen ve Yılmaz, 2012). Katı atık sorununun azaltılmasında çevreye en az zarar verecek uygulama ise atık içerisinde bulunan ve katı atıkların önemli bir kısmını oluşturan kağıt, cam, teneke gibi ekonomik değere sahip ve geri dönüştürülebilir özellikte olan madde türlerinin geri kazanılmasıdır (Hanay ve Koçer, 2006; Çimen ve Yılmaz, 2012). 
Kışoğlu, M. ve Yıldırım, T. (2015). İlkokul ve ortaokullarda çevre eğitimi verecek olan öğretmen adaylarının katı atıklar ve geri dönüşüme yönelik tutumlarının farklı değişkenler açısından incelenmesi. International Journal of Human Sciences, 12(1), 1518-1536. doi: $10.14687 /$ ijhs.v12i1.3283

"Yeniden değerlendirilme imkanı olan atıkların çeşitli işlemlerden geçirilerek hammaddeye ya da ürüne dönüştürülerek tekrar üretime katılmasına geri dönüşüm denir.” (Çimen ve Yılmaz, 2012, s.65). Geri dönüşümün çevre, sağlık ve ekonomiye olumlu katkılarının yanı sıra geri dönüşüm sayesinde kirlilik ve doğal kaynakların tahribatı da önlenmiş olur (Spiegelmand and Sheehan, 2004 akt. Harman et al., 2015). Demir (1995) evsel ve endüstriyel atıklarla birlikte atılan kağıdın, hammaddesi olan orman varlığı için ciddi bir tehdit olduğunu ifade etmiş ve atık kağıdın geri kazanılmasılyla orman varlığının korunmasının yanı sıra kağıt üretiminde oluşan kirliliğin azalacağını, su ve enerji kaynaklarının tasarrufuna imkan sağlanacağını belirtmiştir. Günümüzde pek çok ülke doğal kaynaklarını korumak ve atıkların geleneksel yollarla depolanmasının neden olduğu çevre sorunlarıyla mücadele etmek için atıkların azaltılması ve geri dönüşüm konularına önem vermeye başlamıştır (Kipperberg, 2007).

Toplumda geri dönüşüm bilincinin oluşturulması bireylere geri dönüşüm davranış ve alışkanlığının kazandırılması ile mümkündür. Son yıllarda yapılan araştırmalar çevreye yönelik davranışların çevresel bilgi, etkileşim ve deneyimin yanı sıra çevreye yönelik tutumlardan da etkilendiğini ortaya koymaktadır (Timur v.d., 2013). Bradley et al. (1999) çevre sorunlarının temelinde sorumsuz çevresel davranışların yer aldığını ve davranışları etkileyen en önemli faktörlerden birinin de tutumlar olduğunu ifade etmiştir. Diğer bir ifadeyle bireylerin çevreye yönelik sorumlu davranışlar göstermeleri için çevreye yönelik olumlu tutumlara sahip olmaları gerekir (Karatekin, 2013). Bunun sağlanması ise çevre eğitimiyle mümkündür. Çevre eğitimi ailede başlayıp yakın çevre ve okulla devam eden bir süreçtir (Bener ve Babaoğul, 2008). Bu nedenle bireylerin çevreye yönelik tutumları yaşadıkları yerleşim birimi (Hampel and Holdworth, 1996; Özay Köse, 2010), ailenin gelir düzeyi (Yilmaz et al., 2004; Ercan and Bilen, 2014), annenin eğitim düzeyi (Değirmenci, 2012) ve babanın eğitim düzeyi (Aydın ve Çepni, 2012) gibi değişkenlerden etkilenebilmektedir. Bununla birlikte toplumda çevreye karşı duyarlllk ve bilincin oluşturulmasında gönüllü kuruluşlar veya sivil toplum örgütlerinin de önemli bir yeri vardır (Kahyaoğlu ve Kaya, 2012). Çevreci kuruluşlar çevrenin önemini vurgulayarak insanları çevrenin korunması konusunda bilinçlendirmenin yanı sıra çevreye karşı olumlu ve duyarlı davranışların kazandırılmasında da etkin bir role sahiptir (Kocabaş ve Sarıkaya, 2009).

İlköğretimden yüksek öğretime kadar çevreye duyarlı bireylerin yetiştirilmesinde ve çevre sorunlarının çözülmesinde eğitime önemli görevler düşmektedir (Yllmaz ve Gültekin, 2012). Nitekim Çimen ve Yllmaz (2012) geri dönüşümlü ürünlerin tercih edilmesi gibi çevre koruma davranışlarının kazanılmasında okulun önemini belirtmiş ve öğrencilere geri dönüşümle ilgili çevre bilincinin okullarda kazandırılacağını ifade etmişlerdir. Bu nedenle derslerinde çevre eğitimi veren 
Kışoğlu, M. ve Yıldırım, T. (2015). İlkokul ve ortaokullarda çevre eğitimi verecek olan öğretmen adaylarının katı atıklar ve geri dönüşüme yönelik tutumlarının farklı değişkenler açısından incelenmesi. International Journal of Human Sciences, 12(1), 1518-1536. doi: 10.14687/ijhs.v12i1.3283

öğretmenlerin ve gelecekte çevre eğitimi verecek olan öğretmen adaylarının katı atıklar ve geri dönüşüme yönelik olumlu tutumlara sahip olmaları gerekmektedir. Literatürde yer alan ve öğretmen adaylarının katı atık ve geri dönüşüme yönelik bilgi düzeyleri ve tutumları ile ilgili olarak yapılan çalışmalardan birkaç tanesi şöyle özetlenebilir:

Cici v.d. (2005)'in 216 öğretmen adayının katı atık kirliliği konusunda çevresel farkındalık ve bilgi düzeylerini araştırdıkları çalışmalarında adayların organik atıklar ve paketleme konularındaki çevresel farkındalık düzeylerinin orta, geri dönüşüm ve atık azaltma konularındaki çevresel farkındalık düzeylerinin ise iyi seviyede olduğu sonucuna ulaşılmıştır. Ayrıca öğretmen adaylarının katı atık kirliliği konusunda bilgi düzeylerinin yeterli olmadığı belirtilmiştir.

Tekkaya et al. (2011) iki üniversitede öğrenim gören toplam 232 öğretmen adayının planlanmış davranış teorisi yaklaşımı modeliyle adayların geri dönüşüm davranışlarını inceledikleri çalışmalarında geri dönüşüme yönelik olumlu tutum, kişisel norm ve algılanan davranış kontrolüne sahip öğretmen adaylarının geri dönüşüm davranışı için gerekli olan niyetlerinin daha yüksek olduğu sonucuna varılmışır.

Karatekin (2014)'ün yedi açık uçlu sorudan oluşan bir formla 1., 2., 3. ve 4. sınıfa devam eden 165 sosyal bilgiler öğretmen adayının katı atık ve geri dönüşüm konusundaki bilgi düzeyleri ve farkındalıklarını belirlemeyi amaçladığı çalışmasında öğretmen adaylarının katı atık ve geri dönüşüm konusundaki bilgi düzeyleri ile farkındalıklarının düşük olduğu ifade edilmiştir.

Bir diğer çalışmada ise Harman et al. (2015) birinci sınıfa devam eden 31 fen bilgisi öğretmen adayının geri dönüşüme yönelik tutumlarını etkileyen zihinsel modellerini değerlendirmişlerdir. Çalışma sonunda öğretmen adaylarının geri dönüşüme yönelik tutumlarını etkileyen zihinsel modellerin sayısının sinırlı olduğu bulunmuştur.

Ülkemizde çevre eğitimi ile ilgili konulara ilkokul ve ortaokullarda hayat bilgisi, sosyal bilgiler ve fen bilimleri dersleri kapsamında yer verilmektedir (Karatekin, 2013). Dolayısıyla gelecekte bu derslere girecek olan öğretmen adaylarının katı atık ve geri dönüşüm gibi çevresel konulara yönelik tutumlarının olumlu olması gerekmektedir. Yapılan bu çalısmada fen bilgisi, sınıf ve sosyal bilgiler öğretmen adaylarının katı atık ve geri dönüşüme yönelik tutumları ile adayların tutumlarına cinsiyet, anabilim dalı, yaşanılan yerleşim birimi, ailenin gelir düzeyi, anne ve babanın eğitim durumu, çevreyle ilgili kuruluşlara üyelik ile atıkları ayrıştırarak geri dönüşüm kutusuna atma ve geri dönüşümlü ürünleri tercih etme davranışlarının etkisinin incelenmesi amaçlanmıştır.

\section{Yöntem}

Çalışma tarama modelinde gerçekleştirilmiş betimsel bir araştırmadır. Tarama modeli geçmişte veya halen var olan bir durumu, herhangi bir şekilde etkilemeden ve değiştirmeden, olduğu 
Kışoğlu, M. ve Yıldırım, T. (2015). İlkokul ve ortaokullarda çevre eğitimi verecek olan öğretmen adaylarının katı atıklar ve geri dönüşüme yönelik tutumlarının farklı değişkenler açısından incelenmesi. International Journal of Human Sciences, 12(1), 1518-1536. doi: $10.14687 /$ ijhs.v12i1.3283

haliyle betimlemeyi amaçlayan bir modeldir (Karasar, 1994). Yapılan bu araştırmada öğretmen adaylarının katı atık ve geri dönüşüme yönelik tutumlarının belirlenmesi ve tutumlarına etkisi olabilecek faktörlerin incelenmesi amaçlandığı için araştırmada tarama modeli kullanılmıştır.

Çalışmanın örneklemini ülkemizin İç Anadolu Bölgesinde bulunan bir üniversitesinin Ĕ̆itim Fakültesi bünyesindeki fen bilgisi, sınıf ve sosyal bilgiler öğretmenliği anabilim dalı son sınıfina devam eden 149 öğretmen adayı oluşturmaktadır. Örneklemin son sınıf öğrencilerinden oluşmasının nedeni son sınıfta okuyan öğretmen adaylarının anabilim dalı müfredatlarındaki çevreyle ilgili olan tüm dersleri almış olmaları ve kısa bir süre içerisinde öğretmenlik mesleğine başlayacak olmalarıdır. Diğer taraftan örneklemi oluşturan öğretmen adaylarının fen bilgisi, sınıf ve sosyal bilgiler öğretmen adaylarından oluşmasının nedeni ise ilkokul ve ortaokul öğretim programlarında çevreyle ilgili olan konulara hayat bilgisi, fen bilimleri ve sosyal bilgiler öğretim programlarında yer verilmesidir.

Araştırmanın verileri anket yoluyla elde edilmiştir. Araştırmada kullanılan anket iki bölümden oluşmaktadır. Anketin birinci bölümünde öğretmen adaylarının cinsiyetlerini, öğrenim gördükleri anabilim dallarını, yaşadıkları yerleşim birimini, ailelerinin gelir düzeylerini, ebeveynlerinin öğrenim durumlarını, herhangi bir çevre kuruluşuna üye olup olmadıklarını, atıklarını ayrıştırarak ilgili geri dönüşüm kutularına atıp atmadıklarını ve herhangi bir ürün alırken ürünün geri dönüşüme uygunluğuna dikkat edip etmediklerini belirlemeye yönelik sorular yer almaktadır.

Anketin ikinci bölümünde ise Karatekin (2013) tarafindan geliştirilen 33 maddelik “Öğretmen Adayları İçin Katı Atık ve Geri Dönüşüme Yönelik Tutum Ölçeği” kullanılmıştır. Ölçeğin kullanılmasıyla ilgili olarak araştırmacıdan elektronik posta yoluyla izin alınmıştır. Ölçek beşli likert tipinde geliştirilmiş olup üç faktörden oluşmaktadır. Ölçeğin geliştirilmesi aşamasında Karatekin (2013) tarafından yapılan istatistiksel analizler neticesinde elde edilen ölçeğin üç faktörüne ait madde sayıları ve güvenirlik katsayıları Tablo 1'de özetlenmiştir.

Tablo 1. Öğretmen Adayları İçin Katı Atık ve Geri Dönüşüme Yönelik Tutum Ölçeği’ne ait faktörlerin isimleri, madde sayıları ve güvenirlik katsayıları (Karatekin, 2013)

\begin{tabular}{lcc}
\hline Faktörler & Madde Sayıları & Cronbach's Alpha \\
\hline Girişim ve Katllım & 14 & 0,892 \\
İnanç & 8 & 0,882 \\
İlgi ve Duyarllllk & 11 & 0,877 \\
\hline
\end{tabular}

Veriler SPSS 15.0 programı kullanılarak analiz edilmiştir. Ölçekte yer alan olumsuz maddeler ters çevrilerek kodlanmıştır. Ölçekten alınabilecek en düşük puan 33, en yüksek puan ise 165'tir. Verilerin analizinde kullanılmak üzere öğretmen adaylarının ölçekten aldıkları toplam puanlar 
Kışoğlu, M. ve Yıldırım, T. (2015). İlkokul ve ortaokullarda çevre eğitimi verecek olan öğretmen adaylarının katı atıklar ve geri dönüşüme yönelik tutumlarının farklı değişkenler açısından incelenmesi. International Journal of Human Sciences, 12(1), 1518-1536. doi: $10.14687 /$ ijhs.v12i1.3283

hesaplanmıştır. Veriler bağımsız gruplar t testi ve tek yönlü anova testi kullanılarak analiz edilmiştir. İstatistiksel değerlendirmelerde anlamlılık düzeyi (p) .05 olarak alınmıştır.

\section{Bulgular}

Öğretmen adaylarının katı atık ve geri dönüşüme yönelik tutum ölçeğinden almış oldukları toplam puanlara ait betimsel istatistikler Tablo 2'de özetlenmiştir.

Tablo 2. Öğretmen adaylarının ölçekten almış oldukları toplam puanlara ait betimsel istatistikler

\begin{tabular}{ccccccc}
\hline N & $\bar{X}$ & Mod & Medyan & S.S. & En düşük puan & En yüksek Puan \\
\hline 149 & 121,11 & 120 & 123 & 15,589 & 57 & 155 \\
\hline
\end{tabular}

Tablo 2 incelendiğinde öğretmen adaylarının katı atık ve geri dönüşüme yönelik tutum ölçeğinden almış oldukları toplam puan ortalamalarının $\bar{X}=121,11$ olduğu görülmektedir. Ölçekten alınabilecek en düşük puanın 33, en yüksek puanın 165 olduğu göz önüne alındığında öğretmen adaylarının katı atık ve geri dönüşüme yönelik olarak olumlu bir tutuma sahip oldukları söylenebilir.

Öğretmen adaylarının katı atık ve geri dönüşüme yönelik tutum ölçeği alt boyutu puanlarının cinsiyet analizi sonuçları Tablo 3’te verilmiştir.

Tablo 3. Tutum ölçeği alt boyutu puanlarının cinsiyet analizi sonuçları

\begin{tabular}{cccccccc}
\hline Alt Boyut & Cinsiyet & $\mathrm{N}$ & $\bar{X}$ & S.S. & S.D. & $\mathrm{t}$ & $\mathrm{p}$ \\
\hline Girişim ve Katılım & Bayan & 99 & 50,89 & 6,79 & 147 & 4,421 &, $000^{*}$ \\
& Erkek & 50 & 44,34 & 9,30 & & & \\
\hline İnanç & Bayan & 99 & 30,75 & 3,96 & 147 & 2,362 &, $020^{*}$ \\
& Erkek & 50 & 29,14 & 3,85 & & & \\
\hline Illgi ve Duyarlılık & Bayan & 99 & 43,31 & 4,86 & 147 & 3,024 &, $003^{*}$ \\
& Erkek & 50 & 40,04 & 6,83 & & & \\
\hline
\end{tabular}

${ }^{*} \mathrm{p}<, 05$

Tablo 3 incelendiğinde ölçeğin üç alt boyutunda da öğretmen adaylarının tutumlarında cinsiyete göre istatistiksel olarak anlamlı bir farkllık olduğu belirlenmiştir $(p<, 05)$. Buna göre bayan öğretmen adaylarının katı atık ve geri dönüşüme yönelik tutumları erkek öğretmen adaylarının tutumlarından daha yüksektir.

Öğretmen adaylarının katı atık ve geri dönüşüme yönelik tutum ölçeği alt boyutu puanlarının anabilim dalı analizine ait sonuçlar Tablo 4 ve Tablo 5’te verilmiştir. 
Kışoğlu, M. ve Yıldırım, T. (2015). İlkokul ve ortaokullarda çevre eğitimi verecek olan öğretmen adaylarının katı atıklar ve geri dönüşüme yönelik tutumlarının farklı değişkenler açısından incelenmesi. International Journal of Human Sciences, 12(1), 1518-1536. doi: 10.14687/ijhs.v12i1.3283

Tablo 4. Tutum ölçeği alt boyutu puanlarının anabilim dalı analizi sonuçları

\begin{tabular}{|c|c|c|c|c|}
\hline Alt Boyut & Anabilim Dalı & $\mathrm{N}$ & $\bar{X}$ & S.S \\
\hline \multirow[t]{3}{*}{ Girişim ve Katulım } & Fen Bilgisi (1) & 40 & 51,88 & 6,90 \\
\hline & Sinıf Öğrt. (2) & 40 & 48,45 & 7,47 \\
\hline & Sosyal Bilgiler Öğrt.(3) & 69 & 46,99 & 9,02 \\
\hline \multirow[t]{3}{*}{ İnanç } & Fen Bilgisi (1) & 40 & 31,83 & 3,54 \\
\hline & Sinıf Öğrt.(2) & 40 & 29,30 & 4,27 \\
\hline & Sosyal Bilgiler Öğrt.(3) & 69 & 29,80 & 3,83 \\
\hline \multirow[t]{3}{*}{ İlgi ve Duyarlllik } & Fen Bilgisi (1) & 40 & 44,85 & 4,92 \\
\hline & Sinıf Öğrt. (2) & 40 & 42,68 & 4,44 \\
\hline & Sosyal Bilgiler Öğrt.(3) & 69 & 40,42 & 6,34 \\
\hline
\end{tabular}

Tablo 5. Tutum ölçeği alt boyutu puanlarına anabilim dallarına göre yapılan varyans analizi sonuçları

\begin{tabular}{|c|c|c|c|c|c|c|c|}
\hline Alt Boyut & Varyansın Kaynağ1 & Kareler Toplamı & $\mathrm{sd}$ & Kareler Ortalams & $\mathrm{F}$ & $\mathrm{p}$ & Anlamlı Fark \\
\hline \multirow[t]{3}{*}{ Girişim ve Katulım } & Gruplar aras1 & 608,538 & 2 & 304,269 & 4,644 & , $011^{*}$ & $1-3$ \\
\hline & Gruplar içi & 9565,261 & 146 & 65,515 & & & \\
\hline & Toplam & 10173,799 & 148 & & & & \\
\hline \multirow[t]{3}{*}{ İnanç } & Gruplar aras1 & 149,216 & 2 & 74,608 & 4,953 &, $008^{*}$ & $1-2$ \\
\hline & Gruplar içi & 2199,334 & 146 & 15,064 & & & $1-3$ \\
\hline & Toplam & 2348,550 & 148 & & & & \\
\hline \multirow[t]{3}{*}{ İlgi ve Duyarlilik } & Gruplar aras1 & 508,441 & 2 & 254,220 & 8,343 & , $000^{*}$ & $1-3$ \\
\hline & Gruplar içi & 4448,687 & 146 & 30,470 & & & $2-3$ \\
\hline & Toplam & 4957,128 & 148 & & & & \\
\hline
\end{tabular}

Tablo 4 ve Tablo 5 incelendiğinde öğretmen adaylarının tutum ölçeği alt boyutu puanlarında anabilim dallarına göre anlamlı bir farklılık olduğu görülmektedir $(\mathrm{p}<, 05)$. Ölçeğin girişim ve katılım alt boyutunda fen bilgisi öğretmen adaylarının tutum puanları $\left(\mathrm{X}_{\text {fen bilgisi }}=51,88\right)$ sosyal bilgiler öğretmen adaylarının tutum puanlarından $\left(\mathrm{X}_{\text {sosyal bilgiler }}=46,99\right)$ daha yüksektir. Benzer şekilde ölçeğin inanç alt boyutunda fen bilgisi öğretmen adaylarının tutum puanları $\left(\mathrm{X}_{\text {fen bilgisi }}=31,83\right)$ hem sınıf $\left(X_{\text {stnıf }}=29,30\right)$ hem de sosyal bilgiler öğretmen adaylarının tutum puanlarından $\left(X_{\text {sosyal bilgiler }}=29,80\right)$ daha yüksektir. Ölçeğin ilgi ve duyarlılık alt boyutunda ise fen bilgisi öğretmen adaylarının tutum puanları $\left(\mathrm{X}_{\mathrm{fen}}\right.$ bilgisi $\left.=44,85\right)$ sosyal bilgiler öğretmen adaylarının tutum puanlarından $\left(\mathrm{X}_{\text {sosyal }}\right.$ bilgiler $=40,42)$, sınıf öğretmeni adaylarının tutum puanları ise $\left(X_{\text {smıf }}=42,68\right)$ sosyal bilgiler öğretmen adaylarının tutum puanlarından daha yüksektir.

Öğretmen adaylarının katı atık ve geri dönüşüme yönelik tutum ölçeği alt boyutu puanlarının yerleşim yeri analizine ait sonuçlar Tablo 6 ve Tablo 7 de özetlenmiştir. 
Kışoğlu, M. ve Yıldırım, T. (2015). İlkokul ve ortaokullarda çevre eğitimi verecek olan öğretmen adaylarının katı atıklar ve geri dönüşüme yönelik tutumlarının farklı değişkenler açısından incelenmesi. International Journal of Human Sciences, 12(1), 1518-1536. doi: $10.14687 /$ ijhs.v12i1.3283

Tablo 6. Tutum ölçeği alt boyutu puanlarının yerleşim yeri analizi sonuçları

\begin{tabular}{|c|c|c|c|c|}
\hline Alt Boyut & Yerleşim Yeri & $\mathrm{N}$ & $\bar{X}$ & S.S \\
\hline \multirow[t]{3}{*}{ Girişim ve Katulım } & Köy & 27 & 50,22 & 8,55 \\
\hline & İlçe & 29 & 46,21 & 9,82 \\
\hline & Il & 93 & 49,02 & 7,60 \\
\hline \multirow[t]{3}{*}{ İnanç } & Köy & 27 & 31,22 & 3,84 \\
\hline & İlçe & 29 & 29,83 & 4,43 \\
\hline & İ & 93 & 30,03 & 3,87 \\
\hline \multirow[t]{3}{*}{ İlgi ve Duyarlılık } & Köy & 27 & 43,85 & 5,39 \\
\hline & İlçe & 29 & 41,48 & 7,14 \\
\hline & $\dot{\mathrm{Il}}$ & 93 & 41,96 & 5,40 \\
\hline
\end{tabular}

Tablo 7. Tutum ölçeği alt boyutu puanlarına yerleşim yerine göre yapılan varyans analizi sonuçları

\begin{tabular}{|c|c|c|c|c|c|c|c|}
\hline Alt Boyut & Varyansin Kaynağ1 & Kareler Toplamı & $\mathrm{sd}$ & Kareler Ortalams & $\mathrm{F}$ & $\mathrm{p}$ & Anlamlı Fark \\
\hline \multirow[t]{3}{*}{ Girişim ve Katulım } & Gruplar aras1 & 252,416 & 2 & 126,208 & 1,857 & 160 & - \\
\hline & Gruplar içi & 9921,382 & 146 & 67,955 & & & \\
\hline & Toplam & 10173,799 & 148 & & & & \\
\hline \multirow[t]{3}{*}{ İnanç } & Gruplar aras1 & 34,843 & 2 & 17,421 & 1,099 & ,336 & - \\
\hline & Gruplar içi & 2313,708 & 146 & 15,847 & & & \\
\hline & Toplam & 2348,550 & 148 & & & & \\
\hline \multirow[t]{3}{*}{ İlgi ve Duyarlilik } & Gruplar aras1 & 93,576 & 2 & 46,788 & 1,405 & ,249 & - \\
\hline & Gruplar içi & 4863,552 & 146 & 33,312 & & & \\
\hline & Toplam & 4957,128 & 148 & & & & \\
\hline
\end{tabular}

Tablo 6 ve Tablo 7 incelendiğinde öğretmen adaylarının tutum ölçeğinin üç alt boyutundan almış oldukları puanların yaşanılan yerleşim yerine göre istatistiksel olarak farklılaşmadığı görülmektedir $(\mathrm{p}>, 05)$.

Öğretmen adaylarının katı atık ve geri dönüşüme yönelik tutum ölçeği alt boyutu puanlarının gelir düzeyi analizine ait sonuçlar Tablo 8 ve Tablo 9 da gösterilmiştir.

Tablo 8. Tutum ölçeği alt boyutu puanlarının gelir düzeyi analizi sonuçları

\begin{tabular}{|c|c|c|c|c|}
\hline Alt Boyut & Gelir Düzeyi & $\mathrm{N}$ & $\bar{X}$ & S.S \\
\hline \multirow[t]{5}{*}{ Girişim ve Katulim } & 1000 TL ve alt1 & 49 & 49,67 & 8,20 \\
\hline & 1001-2000 TL & 65 & 48,00 & 8,97 \\
\hline & 2001-3000 TL & 24 & 48,46 & 7,86 \\
\hline & 3001-4000 TL & 8 & 49,50 & 5,83 \\
\hline & 4001 TL ve üzeri & 3 & 47,33 & 4,93 \\
\hline \multirow[t]{5}{*}{ İnanç } & 1000 TL ve alt1 & 49 & 30,65 & 4,18 \\
\hline & 1001-2000 TL & 65 & 29,48 & 4,02 \\
\hline & $2001-3000 \mathrm{TL}$ & 24 & 31,58 & 3,36 \\
\hline & 3001-4000 TL & 8 & 29,13 & 3,31 \\
\hline & 4001 TL ve üzeri & 3 & 30,67 & 4,51 \\
\hline \multirow[t]{5}{*}{ İlgi ve Duyarlilık } & 1000 TL ve alt1 & 49 & 42,88 & 6,36 \\
\hline & $1001-2000$ TL & 65 & 41,14 & 5,56 \\
\hline & 2001-3000 TL & 24 & 44,29 & 5,34 \\
\hline & 3001-4000 TL & 8 & 41,63 & 4,34 \\
\hline & 4001 TL ve üzeri & 3 & 39,67 & 3,51 \\
\hline
\end{tabular}


Kışoğlu, M. ve Yıldırım, T. (2015). İlkokul ve ortaokullarda çevre eğitimi verecek olan öğretmen adaylarının katı atıklar ve geri dönüşüme yönelik tutumlarının farklı değişkenler açısından incelenmesi. International Journal of Human Sciences, 12(1), 1518-1536. doi: 10.14687/ijhs.v12i1.3283

Tablo 9. Tutum ölçeği alt boyutu puanlarına gelir düzeyine göre yapılan varyans analizi sonuçları

\begin{tabular}{|c|c|c|c|c|c|c|c|}
\hline Alt Boyut & Varyansın Kaynağ1 & Kareler Toplamı & $\mathrm{sd}$ & Kareler Ortalams1 & $\mathrm{F}$ & $\mathrm{p}$ & Anlamlı Fark \\
\hline \multirow[t]{3}{*}{ Girişim ve Katulim } & Gruplar aras1 & 90,398 & 4 & 22,600 & ,323 & 862 & - \\
\hline & Gruplar içi & 10083,401 & 144 & 70,024 & & & \\
\hline & Toplam & 10173,799 & 148 & & & & \\
\hline \multirow[t]{3}{*}{ İnanç } & Gruplar aras1 & 99,858 & 4 & 24,964 & 1,599 & ,178 & - \\
\hline & Gruplar içi & 2248,692 & 144 & 15,616 & & & \\
\hline & Toplam & 2348,550 & 148 & & & & \\
\hline \multirow[t]{3}{*}{ İlgi ve Duyarlilik } & Gruplar aras1 & 222,608 & 4 & 55,652 & 1,693 & ,155 & - \\
\hline & Gruplar içi & 4734,519 & 144 & 32,879 & & & \\
\hline & Toplam & 4957,128 & 148 & & & & \\
\hline
\end{tabular}

Tablo 8 ve Tablo 9'a göre öğretmen adaylarının tutum ölçeğinin üç boyutundan da almış oldukları puanlar gelir düzeyine göre farklılaşmamaktadır ( $\mathrm{p}>, 05)$.

Öğretmen adaylarının katı atık ve geri dönüşüme yönelik tutum ölçeği alt boyutu puanlarının ebeveynlerinin eğitim düzeyi analizine ait sonuçlar Tablo 10 ve Tablo 11 de verilmiştir.

Tablo 10. Tutum ölçeği alt boyutu puanlarının ebeveynlerin eğitim düzeyi analizi sonuçları

\begin{tabular}{|c|c|c|c|c|c|}
\hline Değişken & Alt Boyut & Eğitim Düzeyi & $\mathrm{N}$ & $\bar{X}$ & S.S. \\
\hline \multirow{15}{*}{$\begin{array}{l}\text { Anne Eğitim } \\
\text { Düzeyi }\end{array}$} & \multirow{5}{*}{ Girişim ve Katulım } & Okuryazar değil & 18 & 47,39 & 6,54 \\
\hline & & İlkokul mezunu & 108 & 48,71 & 8,76 \\
\hline & & Ortaokul mezunu & 13 & 49,31 & 7,66 \\
\hline & & Lise mezunu & 5 & 51,60 & 5,18 \\
\hline & & Üniversite mezunu & 5 & 48,40 & 9,21 \\
\hline & \multirow{5}{*}{ İnanç } & Okuryazar değil & 18 & 30,94 & 3,54 \\
\hline & & İlkokul mezunu & 108 & 30,33 & 3,85 \\
\hline & & Ortaokul mezunu & 13 & 29,62 & 4,39 \\
\hline & & Lise mezunu & 5 & 28,80 & 5,31 \\
\hline & & Üniversite mezunu & 5 & 27,80 & 6,14 \\
\hline & \multirow{5}{*}{ İlgi ve Duyarlılık } & Okuryazar değil & 18 & 43,78 & 5,21 \\
\hline & & İlkokul mezunu & 108 & 42,06 & 6,04 \\
\hline & & Ortaokul mezunu & 13 & 41,08 & 5,47 \\
\hline & & Lise mezunu & 5 & 44,60 & 2,70 \\
\hline & & Üniversite mezunu & 5 & 40,60 & 4,88 \\
\hline \multirow{15}{*}{$\begin{array}{l}\text { Baba Eğitim } \\
\text { Düzeyi }\end{array}$} & \multirow{5}{*}{ Girişim ve Katılım } & Okuryazar değil & 3 & 49,00 & 7,00 \\
\hline & & İlkokul mezunu & 77 & 48,68 & 9,08 \\
\hline & & Ortaokul mezunu & 30 & 46,70 & 7,84 \\
\hline & & Lise mezunu & 22 & 51,18 & 7,27 \\
\hline & & Üniversite mezunu & 17 & 49,00 & 6,38 \\
\hline & \multirow{5}{*}{ İnanç } & Okuryazar değil & 3 & 33,67 & 3,21 \\
\hline & & İlkokul mezunu & 77 & 30,34 & 3,95 \\
\hline & & Ortaokul mezunu & 30 & 29,40 & 3,98 \\
\hline & & Lise mezunu & 22 & 29,73 & 4,31 \\
\hline & & Üniversite mezunu & 17 & 31,06 & 3,68 \\
\hline & \multirow{5}{*}{ İlgi ve Duyarlllık } & Okuryazar değil & 3 & 45,00 & 6,08 \\
\hline & & İlkokul mezunu & 77 & 42,47 & 5,95 \\
\hline & & Ortaokul mezunu & 30 & 41,23 & 6,09 \\
\hline & & Lise mezunu & 22 & 41,68 & 5,45 \\
\hline & & Üniversite mezunu & 17 & 43,00 & 5,10 \\
\hline
\end{tabular}


Kışoğlu, M. ve Yıldırım, T. (2015). İlkokul ve ortaokullarda çevre eğitimi verecek olan öğretmen adaylarının katı atıklar ve geri dönüşüme yönelik tutumlarının farklı değişkenler açısından incelenmesi. International Journal of Human Sciences, 12(1), 1518-1536. doi: 10.14687/ijhs.v12i1.3283

Tablo 11. Tutum ölçeği alt boyutu puanlarına ebeveynlerin eğitim durumuna göre yapılan varyans analizi sonuçları

\begin{tabular}{|c|c|c|c|c|c|c|c|c|}
\hline Değişken & Alt Boyut & $\begin{array}{l}\text { Varyansin } \\
\text { Kaynağ1 }\end{array}$ & $\begin{array}{l}\text { Kareler } \\
\text { Toplamı }\end{array}$ & $\mathrm{sd}$ & $\begin{array}{c}\text { Kareler } \\
\text { Ortalamas1 }\end{array}$ & $\mathrm{F}$ & $\mathrm{p}$ & $\begin{array}{l}\text { Anlamli } \\
\text { Fark }\end{array}$ \\
\hline \multirow{9}{*}{$\begin{array}{l}\text { Anne } \\
\text { Eğitim } \\
\text { Düzeyi }\end{array}$} & Girişim ve & Gruplar aras1 & 78,250 & 4 & 19,562 & ,279 & ,891 & - \\
\hline & Katulım & Gruplar içi & 10095,549 & 144 & 70,108 & & & \\
\hline & & Toplam & 10173,799 & 148 & & & & \\
\hline & İnanç & Gruplar aras1 & 54,929 & 4 & 13,732 & ,862 & ,488 & - \\
\hline & & Gruplar içi & 2293,621 & 144 & 15,928 & & & \\
\hline & & Toplam & 2348,550 & 148 & & & & \\
\hline & İlgi ve & Gruplar aras1 & 105,027 & 4 & 26,257 & ,779 & ,540 & - \\
\hline & Duyarlilik & Gruplar içi & 4852,101 & 144 & 33,695 & & & \\
\hline & & Toplam & 4957,128 & 148 & & & & \\
\hline \multirow{9}{*}{$\begin{array}{l}\text { Baba } \\
\text { Eğitim } \\
\text { Düzeyi }\end{array}$} & Girişim ve & Gruplar aras1 & 257,343 & 4 & 64,336 & ,934 & ,446 & - \\
\hline & Katulım & Gruplar içi & 9916,456 & 144 & 68,864 & & & \\
\hline & & Toplam & 10173,799 & 148 & & & & \\
\hline & İnanç & Gruplar aras1 & 74,158 & 4 & 18,540 & 1,174 & ,325 & - \\
\hline & & Gruplar içi & 2274,392 & 144 & 15,794 & & & \\
\hline & & Toplam & 2348,550 & 148 & & & & \\
\hline & İlgi ve & Gruplar aras1 & 73,819 & 4 & 18,455 & ,544 & ,704 & - \\
\hline & Duyarlilik & Gruplar içi & 4883,308 & 144 & 33,912 & & & \\
\hline & & Toplam & 4957,128 & 148 & & & & \\
\hline
\end{tabular}

Tablo 10 ve Tablo 11'de özetlenen analiz sonuçları öğretmen adaylarının tutum ölçeğinin üç alt boyutundan elde etmiş oldukları tutum puanlarının anne ve babalarının eğitim düzeylerine göre farklılaşmadığını göstermektedir ( $\mathrm{p}>, 05)$.

Araştırmaya katılan öğretmen adaylarının katı atık ve geri dönüşüme yönelik tutum ölçeği alt boyutu puanlarının çevre kuruluşuna üyelik analizi sonuçları Tablo 12'de özetlenmiştir.

Tablo 12. Tutum ölçeği alt boyutu puanlarının çevre kuruluşuna üyelik analizi sonuçları

\begin{tabular}{clcccccc}
\hline Alt Boyut & Üyelik Durumu & $\mathrm{N}$ & $\bar{X}$ & S.S. & S.D. & $\mathrm{t}$ & $\mathrm{p}$ \\
\hline Girişim ve Katılım & Üye & 17 & 49,29 & 4,93 & 147 &, 481 &, 634 \\
& Üye değil & 132 & 48,61 & 8,64 & & & \\
\hline \multirow{2}{*}{ Inanç } & Üye & 17 & 30,35 & 3,02 & 147 & \multirow{2}{*}{, 159} &, 874 \\
& Üye değil & 132 & 30,19 & 4,10 & & & \\
\hline İlgi ve Duyarlilık & Üye & 17 & 43,29 & 4,16 & 147 & \multirow{2}{*}{, 816} &, 416 \\
& Üye değil & 132 & 42,08 & 5,96 & & & \\
\hline
\end{tabular}

Tablo incelendiğinde ölçeğin her üç alt boyutunda da çevre kuruluşuna üye olan öğretmen adaylarının tutumlarının üye olmayanların tutumlarından yüksek olmakla birlikte, bu farkın istatistiksel olarak anlamlı olmadığı görülmektedir ( $\mathrm{p}>, 05)$.

Öğretmen adaylarının katı atık ve geri dönüşüme yönelik tutum ölçeği alt boyutu puanlarının atıkları ayrıştırarak ilgili olduğu geri dönüşüm kutusuna atma durumuna göre farklılaşıp farklılaşmadığını belirlemeye yönelik olarak yapılan analiz sonuçları Tablo 13’te özetlenmiştir. 
Kışoğlu, M. ve Yıldırım, T. (2015). İlkokul ve ortaokullarda çevre eğitimi verecek olan öğretmen adaylarının katı atıklar ve geri dönüşüme yönelik tutumlarının farklı değişkenler açısından incelenmesi. International Journal of Human Sciences, 12(1), 1518-1536. doi: $10.14687 /$ ijhs.v12i1.3283

Tablo 13. Tutum ölçeği alt boyutu puanlarının atıkları ayrıştırarak ilgili geri dönüşüm kutusuna atma durumuna göre yapılan analiz sonuçları

\begin{tabular}{|c|c|c|c|c|c|c|c|}
\hline Alt Boyut & $\begin{array}{l}\text { Atıkları ayrışturarak } \\
\text { ilgili geri dönüşüm } \\
\text { kutusuna atma durumu }\end{array}$ & $\mathrm{N}$ & $\bar{X}$ & S.S. & S.D. & $\mathrm{t}$ & $\mathrm{p}$ \\
\hline \multirow[t]{2}{*}{ Girişim ve Katulım } & Ayrişturarak atanlar & 57 & 52,49 & 6,64 & 147 & 4,708 &, $000^{*}$ \\
\hline & Ayrışturmadan atanlar & 92 & 46,34 & 8,37 & & & \\
\hline \multirow[t]{2}{*}{ İnanç } & Ayrıştırarak atanlar & 57 & 30,70 & 4,14 & 147 & 1,192 & 235 \\
\hline & Ayrıştırmadan atanlar & 92 & 29,90 & 3,87 & & & \\
\hline \multirow[t]{2}{*}{ İlgi ve Duyarlilik } & Ayrıștırarak atanlar & 57 & 44,37 & 4,75 & 147 & 3,728 &, $000^{*}$ \\
\hline & Ayrrștırmadan atanlar & 92 & 40,88 & 5,99 & & & \\
\hline
\end{tabular}

Tabloya göre ölçeğin girişim ve katılım alt boyutunda atıklarını ayrıştırarak atanların tutum puanı ( $\bar{X}=52,49)$, ayrıştırmadan atanların tutum puanından $(\bar{X}=46,34)$ istatistiksel olarak daha yüksektir $(\mathrm{p}<, 05)$. Benzer şekilde ölçeğin ilgi ve duyarllık alt boyutunda atıklarını ayrıştırarak atanların tutum puanı $(\bar{X}=44,37)$ ayırmadan atanların tutum puanından $(\bar{X}=40,88)$ istatistiksel olarak daha yüksektir $(p<, 05)$. Ölçeğin inanç alt boyutunda ise atıklarını ayrıştırarak atan ve atmayan öğretmen adaylarının tutum puanları arasında istatistiksel olarak anlamlı bir fark bulunmamaktadır $(\mathrm{p}>, 05)$.

Öğretmen adaylarının tutum ölçeği alt boyutu puanlarının geri dönüşüme uygun ürünleri tercih etme davranışlarına göre yapılan analiz sonuçları Tablo 14’te özetlenmiştir.

Tablo 14. Tutum ölçeği alt boyutu puanlarının geri dönüşüme uygun ürünleri tercih etme davranışlarına göre yapılan analiz sonuçları

\begin{tabular}{|c|c|c|c|c|c|c|c|}
\hline Alt Boyut & $\begin{array}{l}\text { Geri dönüşümlü } \\
\text { ürünleri tercih durumu }\end{array}$ & $\mathrm{N}$ & $\bar{X}$ & S.S. & S.D. & $\mathrm{t}$ & $\mathrm{p}$ \\
\hline \multirow[t]{2}{*}{ Girişim ve Katılım } & Tercih edenler & 37 & 52,95 & 7,45 & 147 & 3,756 &, $000^{*}$ \\
\hline & Tercih etmeyenler & 112 & 47,29 & 8,10 & & & \\
\hline \multirow[t]{2}{*}{ İnanç } & Tercih edenler & 37 & 30,76 & 3,63 & 147 & 966 & ,336 \\
\hline & Tercih etmeyenler & 112 & 30,03 & 4,09 & & & \\
\hline \multirow[t]{2}{*}{ İlgi ve Duyarlilik } & Tercih edenler & 37 & 44,22 & 4,84 & 147 & 2,468 &, $015^{*}$ \\
\hline & Tercih etmeyenler & 112 & 41,55 & 5,94 & & & \\
\hline
\end{tabular}

Analiz sonucunda ölçeğin girişim ve katıllım alt boyutunda geri dönüşümlü ürünleri tercih eden öğretmen adaylarının tutum puanlarının $(\bar{X}=52,95)$ tercih etmeyen öğretmen adaylarının tutum puanlarından $(\bar{X}=47,29)$ istatistiksel olarak daha yüksek olduğu bulunmuştur $(p<, 05)$. Yine analiz sonuçları ölçeğin ilgi ve duyarlllı alt boyutunda geri dönüşümlü ürünleri tercih eden öğretmen adaylarının tutum puanlarının $(\bar{X}=44,22)$ tercih etmeyen öğretmen adaylarının tutum puanlarından $(\bar{X}=41,55)$ daha yüksek olduğunu göstermiştir $(p<, 05)$. Bununla birlikte ölçeğin inanç alt boyutunda 
Kışoğlu, M. ve Yıldırım, T. (2015). İlkokul ve ortaokullarda çevre eğitimi verecek olan öğretmen adaylarının katı atıklar ve geri dönüşüme yönelik tutumlarının farklı değişkenler açısından incelenmesi. International Journal of Human Sciences, 12(1), 1518-1536. doi: $10.14687 /$ ijhs.v12i1.3283

geri dönüşümlü ürünleri tercih eden ve etmeyen öğretmen adaylarının tutum puanları arasında istatistiksel olarak herhangi bir farklıllğın olmadığı belirlenmiştir ( $\mathrm{p}>, 05)$.

\section{Tartışma ve Yorum}

Mezun olduklarında ilkokul ve ortaokullarda çevre eğitimi verecek olan fen bilgisi, sınıf ve sosyal bilgiler öğretmen adaylarının katı atık ve geri dönüşüme yönelik tutumlarının çeşitli değişkenler açısından incelenmesini amaçlayan çalışmanın sonunda öğretmen adaylarının katı atık ve geri dönüşüme yönelik tutumlarının olumlu olduğu belirlenmiştir. Elde edilen bu sonuç Cici v.d. (2005) tarafindan yapılan ve öğretmen adaylarının geri dönüşüm ve katı atık azaltma konusundaki çevresel farkındalıklarının iyi düzeyde olduğunu gösteren araştırma sonucuyla örtüşmektedir. Öğretmenler toplumu ve öğrencileri çevre konusunda bilgilendirmede ve çevreye duyarlı bireyler haline getirmede önemli bir role sahiptirler (Kaur, 2013). Eğer öğretmen adayları eğitim fakültelerindeki öğrenimleri boyunca çevreye duyarlı bireyler yetiştirilirse mesleğe başladıklarında bu duyarlılıklarını öğrencilerine aktarabilirler (Karataş, 2013). Dolayısıyla çevre eğitimi verecek olan öğretmen adaylarının çevreye yönelik olumlu tutumlara sahip olmaları gerektiğinden hareketle (Karatekin, 2013) araştırma neticesinde elde edilen bu bulgunun oldukça önemli olduğu düşünülmektedir.

Katı atık ve geri dönüşüme yönelik tutum ölçeğinin üç alt boyutunda da (Girişim ve katılım, inanç, ilgi ve duyarlılık) bayan öğretmen adaylarının tutumlarının erkek öğretmen adaylarının tutumlarından daha yüksek olduğu bulunmuştur (Tablo 3). Cici v.d. (2005)'de öğretmen adaylarının katı atık kirliliği bağlamında çevresel farkındalık ve bilgi düzeylerini belirlemeyi amaçladığ1 çalışmasında atıkların azaltılması boyutunda bayan öğretmen adaylarının farkındalıklarının erkek öğretmen adaylarının farkındalıklarından daha yüksek olduğu sonucuna ulaşmıştır. Bununla birlikte literatürde konuyla ilgili olarak yapılan çalışmalar bayan öğretmen adaylarının erkek öğretmen adaylarına göre çevreye karşı daha duyarlı olduklarını, çevre ve çevre sorunlarına yönelik tutumlarının da daha yüksek olduğunu göstermektedir (Çabuk ve Karacaoğlu, 2003; Şama, 2003; Erol and Gezer, 2006; Kayalı, 2010; Kahyaoğlu ve Özgen, 2012; Özsoy et al., 2011). Bu durumun toplumun erkek ve bayanlara yüklemiş olduğu sorumluluklardan kaynaklanabileceği düşünülmektedir. Özsoy et al. (2011) yapmış oldukları çalışmalarında, bayan öğretmen adaylarının çevreye yönelik tutumlarının erkek öğretmen adaylarınınkinden yüksek olmasının nedeninin kadın ve erkeğe yüklenen geleneksel roller olabileceğini ifade etmişlerdir. Tikka et al. (2000)'de konuyla ilgili literetürde erkeklerin doğayı kontrol etme ve doğal kaynaklardan yararlanma, bayanların ise doğaya karşı daha duygusal tutumlara sahip olduklarının kabul edildiğini; temiz ve güvenli bir çevrenin sağlıklı yaşamın devamı için gerekli olduğu düşüncesinden hareketle, geleneksel anlamda 
Kışoğlu, M. ve Yıldırım, T. (2015). İlkokul ve ortaokullarda çevre eğitimi verecek olan öğretmen adaylarının katı atıklar ve geri dönüşüme yönelik tutumlarının farklı değişkenler açısından incelenmesi. International Journal of Human Sciences, 12(1), 1518-1536. doi: $10.14687 /$ ijhs.v12i1.3283

evinden ve çocuğunun bakımından sorumlu tutulan bayanların çevre hakkında daha çok endişe duyduklarını ifade etmişlerdir.

Öğretmen adaylarının katı atık ve geri dönüşüme yönelik tutum ölçeği puanlarının anabilim dalı analizi sonuçlarına göre ölçeğin her üç alt boyutunda da fen bilgisi eğitimi anabilim dalı öğrencilerinin puan ortalamalarının sınıf öğretmenliği ve sosyal bilgiler öğretmenliği anabilim dalı öğrencilerinden daha yüksek olduğu sonucuna varılmıştır. Bu fark girişim ve katılım alt boyutunda fen bilgisi ile sosyal bilgiler, inanç alt boyutunda fen bilgisi ile hem sınıf öğretmenliği hem sosyal bilgiler, ilgi ve duyarlllık alt boyutunda ise yine fen bilgisi ve sosyal bilgiler öğretmenliği anabilim dalları arasında fen bilgisi öğretmen adayları lehinde istatistiksel olarak anlamlıdır. Sosyal bilgiler öğretmenliği anabilim dalı öğrencilerinin tutum ölçeği alt boyutu puan ortalamaları ise girişim ve katılım alt boyutu ile inanç alt boyutunda fen bilgisi öğretmenliği, ilgi ve duyarllık alt boyutunda ise hem fen bilgisi hem de sınıf öğretmenliği öğrencilerinin tutum puanlarından istatistiksel olarak daha düşüktür (Tablo 4 ve Tablo 5). Elde edilen bu sonuç Karatekin (2014) tarafından yapılan ve sosyal bilgiler öğretmen adaylarının katı atık ve geri dönüşüm konusundaki farkındalıklarının çok düşük olduğunu gösteren araştırma bulgusuyla paralellik göstermektedir. Farklı anabilim dallarında öğrenim gören öğretmen adaylarının katı atık ve geri dönüşüme yönelik tutumlarında görülen farklılı̆̆ın nedeni anabilim dallarında çevre ile ilgili olan ders sayısından kaynaklanabilir. Fen bilgisi, sınıf öğretmenliği ve sosyal bilgiler öğretmenliği anabilim dallarının müfredat programları incelendiğinde, seçmeli dersler hariç, çevre ve çevre sorunları ile ilgili ders sayısının fen bilgisi öğretmenliği anabilim dalında sinıf ve sosyal bilgiler öğretmenliği anabilim dallarındaki ders sayısından daha fazla olduğu görülmektedir.

Araştırma bulguları öğretmen adaylarının katı atık ve geri dönüşüme yönelik tutumlarının adayların yaşadıkları yerleşim birimi, ailelerinin gelir düzeyi ve ebeveynlerinin eğitim seviyesine göre farklılaşmadığını göstermektedir (Tablo 6, 7, 8, 9, 10 ve 11). Araştırma sonucunda elde edilen bu bulgular literatürde yer alan ve öğretmen adaylarının çevre ve çevre sorunlarına yönelik tutum ve duyarlılıklarının yaşanılan yerleşim birimine (Gürbüz ve Çakmak, 2012; Polat ve Kırpık, 2013), ailenin gelir düzeyine (Erol and Gezer, 2006; Geçikli, 2013; Ercengiz v.d., 2014) ve adayların ebeveynlerinin eğitim seviyesine (Ercengiz v.d., 2014) göre farklılaşmadığını gösteren araştırma sonuçlarıyla örtüşmektedir. Böyle bir sonucun ortaya çıkmasında çevre sorunlarının toplumun her kesimini etkileyen özelliğinin etkili olduğu düşünülmektedir. Nitekim Erten (2004), çevre sorunlarının en büyük özelliğinin etkilerinin lokal değil global düzeyde görülmesi olduğunu ifade etmiş ve çevre sorunlarının din, dil, ırk, zengin-fakir, köylü-şehirli ayrımı olmaksızın toplumun bütün kesimini etkilediğini belirtmiştir. Dolayısıyla öğretmen adaylarının katı atık ve geri dönüşüme 
Kışoğlu, M. ve Yıldırım, T. (2015). İlkokul ve ortaokullarda çevre eğitimi verecek olan öğretmen adaylarının katı atıklar ve geri dönüşüme yönelik tutumlarının farklı değişkenler açısından incelenmesi. International Journal of Human Sciences, 12(1), 1518-1536. doi: 10.14687/ijhs.v12i1.3283

yönelik tutumlarının yaşadıkları yerleşim birimi, ailelerinin gelir düzeyi, anne ve babalarının eğitim seviyesine göre farklılaşmaması çevre sorunlarının toplumun bütün kesimini etkileyen global etkilerinden dolayı beklenen bir sonuç olarak yorumlanabilir.

Araştırma sonucunda öğretmen adaylarının katı atık ve geri dönüşüme yönelik tutumlarının adayların çevre kuruluşuna üye olup olmamalarına göre farklılaşmadığı belirlenmiştir (Tablo 12). Elde edilen bu bulgu Yenice et al. (2008)'in yapmış olduğu ve öğretmen adaylarının çevresel duyarlılıklarının çevreyle ilgili bir kuruluşa üye olup olmamalarına göre farklılaşmadığını gösteren araştırma sonucuyla benzerlik göstermektedir. Bu sonucun ortaya çıkmasında çevre kuruluşuna üye olan öğretmen adaylarının sayısının azlığının etkili olduğu düşünülmektedir. Nitekim araştırmada çevreyle ilgili herhangi bir kuruluşa üye olan öğretmen adaylarının sayısı üye olmayan öğretmen adaylarının sayısından oldukça düşüktür (Tablo 12). Konuyla ilgili olarak yapılan çalısmalar da üniversite düzeyinde öğrenim gören öğrencilerin çevre ile ilgili organizasyonlarda aktif olarak görev almadıklarını ortaya koymaktadır (Çabuk ve Karacaoğlu, 2003; Özmen v.d., 2005). Gürbüz ve Çakmak (2012) tarafindan yapılan çalışmada çevre kuruluşuna üye olan biyoloji öğretmeni adaylarının sayısının oldukça az olduğu bulunmuştur. Bu sayısal dezavantaja rağmen katı atık ve geri dönüşüme yönelik tutum ölçeğinin üç alt boyutunda da çevre kuruluşuna üye olan ve olmayan öğretmen adaylarının puan ortalamaları arasında çevre kuruluşuna üye olanların lehine bir farklılık olmasina rağmen, bu farklılık istatistiksel olarak anlamlı değildir (Tablo 12). Uzun ve Sağlam (2007)'a göre bu durumun temel nedeni çevre kuruluşlarının öğrencilere yeterince tanıtılamaması ve yapmış oldukları çalışmalarda bir takım eksikliklerin bulunmasıdır.

Atıkları ayrıştırarak ilgili geri dönüşüm kutusuna atma ve geri dönüşümlü ürünleri tercih etme davranışlarının katı atık ve geri dönüşüme yönelik tutumlara etkisinin araştırılması neticesinde ölçeğin girişim ve atılım alt boyutu ile ilgi ve duyarlılık alt boyutu puan ortalamaları arasında atıklarını ayrıştırarak ilgili geri dönüşüm kutusuna atanlar ve geri dönüşümlü ürünleri tercih edenler lehinde anlamlı bir farklılık olduğu bulunmuştur. Buna rağmen katı atık ve geri dönüşüme yönelik tutum ölçeğinin inanç alt boyutunda atıkları ayrıştırarak ilgili geri dönüşüm kutusuna atma ile geri dönüşümlü ürünleri tercih etme davranışlarının herhangi bir etkisinin olmadığı belirlenmiştir (Tablo 13 ve Tablo 14). Amerika Birleşik Devletleri’nde yapılan bir araştırmada tüketicilerin büyük bir çoğunluğunun çevre sorunları hakkında kayg1 duydukları (\%87) ve herhangi bir ürün satın alırken üretici firmanın çevreci uygulamalarına dikkat ettikleri (\%79) belirlenmiştir (Makower, 2007). Dolayısıyla araştırma sonucunda geri dönüşüme yönelik olarak ilgi ve duyarlılı̆g yüksek olan bireylerin duyarlı geri dönüşüm davranışları (girişim ve katılım) sergilemeleri beklenen bir sonuç olarak değerlendirilmektedir. 
Kışoğlu, M. ve Yıldırım, T. (2015). İlkokul ve ortaokullarda çevre eğitimi verecek olan öğretmen adaylarının katı atıklar ve geri dönüşüme yönelik tutumlarının farklı değişkenler açısından incelenmesi. International Journal of Human Sciences, 12(1), 1518-1536. doi: $10.14687 /$ ijhs.v12i1.3283

Araştırma sonucunda elde edilen bulgular ışı̆̆ında aşağıdaki önerilerin dikkate alınmasının önemli olduğu düşünülmektedir:

1. Öğretmen adaylarına verilen çevre eğitiminde adaylara geri dönüşüme yönelik duyarlllık ve davranış kazandırılmasına dönük, öğrenci merkezli etkinliklere önem verilmeli ve bu etkinliklere erkek öğretmen adaylarının katılımı sağlanmalıdır.

2. Özellikle öğretmen olduklarında çevre eğitimi verecek olan öğretmen adaylarının öğrenim gördüğü bölüm ve anabilim dallarında çevreyle ilgili derslerin sayısı artırilmalidir.

3. Öğretmen adaylarına çevre kuruluşları tanıtılmalı ve adayların yasal olan çevre kuruluşlarına üyelikleri desteklenmelidir.

4. Geri dönüşüm konusunda toplumun bütün kesimini kapsayacak eğitim programları düzenlenmeli ve mevcut eğitim programlarına öğretmen adaylarının katılımı sağlanmalıdır.

\section{Kaynakça}

Anand, S.V. (2013). Global environmental issues. 2: 632 doi: 10.4172/scientificreports.632

Aydın, F., Çepni, O. (2012). İlköğretim ikinci kademe öğrencilerinin çevreye yönelik tutumlarının bazı değişkenler açısından incelenmesi. Dicle Üniversitesi Ziya Gökalp Eğitim Fakültesi Dergisi, 18, 189-207.

Bener, Ö., Babaoğul, M. (2008). Sürdürülebilir tüketim davranış1 ve çevre bilinci oluşturmada bir araç olarak tüketici eğitimi. Hacettepe Üniversitesi Sosyolojik Arastırmalar E-dergisi, http://www.sdergi.hacettepe.edu.tr/makaleler/surdurulebilirtuketimdavranisi.pdf (30.01.2015)

Bradley, J.C., Walıczek, T.M., Zajıcek, J.M. (1999). Relationship Between Environmental Knowledge and Environmental Attitude of High School Students. Journal of Environmental Education, 30(3), 17-21.

Cici, M., Şahin, N., Şeker, H., Görgen, İ., Deniz, S. (2005). Öğretmen adaylarının katı atık kirliliği bağlamında çevresel farkındalık ve bilgi düzeyleri. Eğitim Bilimleri ve Uygulama, 4(7), 37-50.

Çabuk, B., Karacaoğlu, B. (2003). Üniversite öğrencilerinin çevre duyarllıklarının incelenmesi. Ankara Üniversitesi Eğitim Bilimleri Fakültesi Dergisi, Cilt:36, Say1:1-2, 189-198.

Çimen, O., Yılmaz, M. (2012). İlköğretim öğrencilerinin geri dönüşümle ilgili bilgileri ve geri dönüşüm davranışları. Uludă̆ Üniversitesi Eğitim Fakültesi Dergisi, 25(1), 63-74.

Değirmenci, M. (2012). İlköğretim öğrencilerinin çevreye karşı tutumlarının farklı değişkenler açısından incelenmesi (Kayseri ili örneği). Journal of European Education, 2(2), 47-53. 
Kışoğlu, M. ve Yıldırım, T. (2015). İlkokul ve ortaokullarda çevre eğitimi verecek olan öğretmen adaylarının katı atıklar ve geri dönüşüme yönelik tutumlarının farklı değişkenler açısından incelenmesi. International Journal of Human Sciences, 12(1), 1518-1536. doi: $10.14687 /$ ijhs.v12i1.3283

Demir, A. (1995). Atık kağıdın geri dönüşümü ve ülke ekonomisine net katkıları. Ekooloji, 15, 27 29.

Ercan, O., Bilen, K. (2014). A research on electronic waste awareness and environmental attitudes of primary school students. Anthropologist, 17(1), 13-23.

Ercengiz, M., Keçeci Kurt, S., Polat, S. (2014). Öğretmen adaylarının çevre sorunlarına yönelik duyarllıklarının incelenmesi (Ağrı ili örneği). EKEV Akademi Dergisi, Yı1:18, Sayı:59, 119132.

Erol, G.H., Gezer, K. (2006). Prospective of Elementary School Teachers’ Attitudes Toward Environment and Environmental Problems. International Journal Of Environmental and Science Education, Vol 1 No: 1, 65 - 77.

Erten, S. (2004). Çevre eğitimi ve çevre bilinci nedir, çevre eğitimi nasıl olmalıdır?, Cevre ve Insan Dergisi, Çevre ve Orman Bakanluğg Yaym Organ. Sayı 65/66. 2006/25 Ankara 12.

Geçikli, E. (2013). "Student teachers' attitudes towards nature and the environment". ICOEST Cappadocia 2013, Nevşehir Üniversitesi, Türkiye.

Gürbüz, H., Çakmak, M. (2012). Biyoloji eğitimi bölümü öğrencilerinin çevreye yönelik tutumlarının incelenmesi. Dicle Üniversitesi Ziya Gökalp Ë̈itim Fakültesi Dergisi, 19, 162-173.

Hampell, B., Holdsworth, R. (1996). Environmental consciousness A study in six victorian secondary schools. http://web.education.unimelb.edu.au/yrc/linked_documents/RR12.pdf (10.02.2015).

Hanay, Ö., Koçer, N. (2006). Elazığ kenti katı atıkları geri kazanım potansiyelinin belirlenmesi. Firat Üniversitesi Fen ve Mühendislik Bilimleri Dergisi, 18(4), 507-511.

Harman, G., Aksan, Z., Çelikler, D. (2015). Mental Models which Influence the Attitudes of Science Students towards Recycling. International Journal of Sustainable and Green Energy, 4(12), 6-11.

Kahyaoğlu, M., Kaya, M.F. (2012). Öğretmen adaylarının çevre kirliliğine ve çevreyle ilgili sivil toplum örgütlerine yönelik görüşleri. Ë̈itim Bilimleri Araștırmaları Dergisi Uluslar arası EDergi, 2(1), 91-107.

Kahyaoğlu, M., Özgen, N. (2012). Öğretmen adaylarının çevre sorunlarına yönelik tutumlarının çeşitli değişkenler açısından incelenmesi. Kuramsal Ë̆itimbilim Dergisi, 5(2), 171-185.

Karasar, N. (1994). Bilimsel Araştırma Yöntemi: Kavramlar, İlkeler, Teknikler. 3A Araştırma Eğitim Danışmanlık Ltd., Ankara.

Karataş, A. (2013). The role of faculties of education in increasing sustainable environmental awareness of society. European Journal of Sustainable Development, 2(4), 233-242.

Karatekin, K. (2013). Öğretmen adayları için katı atık ve geri dönüşüme yönelik tutum ölçeğinin geliştirilmesi: Geçerlik ve güvenirlik çalışması. Uluslar arası Avrasya Sosyal Bilimler Dergisi, 4(10), 71-90.

Karatekin, K. (2014). Social studies pre-service teachers' awareness of solid waste and recycling. Procedia - Social and Behavioral Sciences, 116, 1797-1801.

Kaur, S. (2013). Role of teachers in imparting environmental education for sustainable development. International Educational E-Journal, Vol:2, Issue:2, 10-16. 
Kışoğlu, M. ve Yıldırım, T. (2015). İlkokul ve ortaokullarda çevre eğitimi verecek olan öğretmen adaylarının katı atıklar ve geri dönüşüme yönelik tutumlarının farklı değişkenler açısından incelenmesi. International Journal of Human Sciences, 12(1), 1518-1536. doi: $10.14687 /$ ijhs.v12i1.3283

Kayalı, H. (2010). Sosyal bilgiler, Türkçe ve sınıf öğretmenliği öğretmen adaylarının çevre sorunlarına yönelik tutumları. Marmara Coğrafja Dergisi, 21, 258-268.

Khan, Z.A. (2013). Global environmental issues and its remedies. International Journal of Sustainable Energy and Environment, 1(8), 120-126.

Kimani, N.G. (2007). Environmental Pollution and Impact to Public Health; Implication of the Dandora Municipal Dumping Site in Nairobi, Kenya.

http://www.kutokanet.com/Storage/UNEP Dandora Environmental Pollution and Im pact To Public Health 2007.pdf (29.01.2015)

Kipperberg, G. (2007). A comparison of household recycling behaviors in Norway and the United States. Environmental and Resource Economics, 36, 215-235.

Kocabaş, F., Sarıkaya, M. (2009). İşletmelerin gönüllü çevreci kuruluşlarla ilişskisi ve istihdam politikalarındaki rolü. "Iș, Güç” Endüstri İlişkileri ve İnsan Kaynaklar Dergisi, Cilt:11, Sayı:1, 54 72.

Koçer, N., Işık, H. (2005). Öğrenci yurdu katı atıklarının geri kazanımının ekonomik açıdan araştırılması. Pamukkeale Üniversitesi Mühendislik. Fakültesi Mühendislik Bilimleri Dergisi, 11(3), 373-380.

Makower, J. (2007). What's the behind the gren consumer research? http://www.greenbiz.com/blog/2007/09/15/whats-behind-green-consumer-research (07.04.2015)

Milli Eğitim Bakanlı̆̆ (MEB). (2009). Cevre Koruma Katı Atık Toplama. http://hbogm.meb.gov.tr/modulerprogramlar/kursprogramlari/cevrekoruma/moduller/k ati atik toplama.pdf $(29.01 .2015)$

Minghua, Z., Xiumin, F., Rovetta, A., Qichang, H., Vicentini, F., Bingkai, L., Giusti, A., Yi, L. (2009). Municipal solid waste management in Pudong New Area, China. Waste Management, $29,1227-1233$.

Mutlu, M. (2013). "Recycling" concepts perceptions of grade eihgth students: A phenomenographic analysis. Anthropologist, 16(3), 663-669.

Özay Köse, E. (2010). Lise öğrencilerinin çevreye yönelik tutumlarına etki eden faktörler. Türk Fen Eğitimi Dergisi, 7(3), 198-211.

Özmen, D., Çetinkaya, A.Ç., Nehir, S. (2005). Üniversite öğrencilerinin çevre sorunlarına yönelik tutumları. TSK Koruyucu Hekimlik Bülteni, 4(6), 330-344.

Özsoy, S., Özsoy, G., Kuruyer H. G. (2011).Turkish pre-service primary school teachers' environmental attitudes: Effects of gender and grade level. Asia Pacific Forum on Science Learning and Teaching, Vol. 12, Issue 2, Article 5.

Polat, S., Kırpık, C. (2013). Öğretmen adaylarının çevre sorunlarına yönelik tutumları. Bartın Üniversitesi Eğitim Fakültesi Dergisi, Cilt:2, Say1:1, 205-227.

Şama, E. (2003). Öğretmen adaylarının çevre sorunlarına yönelik tutumları. G.Ü. Gaz̨i Eğitim Fakïltesi Dergisi, Cilt:23, Say1:2, 99-110.

Tekkaya, C., Kiliç, D.S., Sahin, E. (2011). A study on teacher candidates' recycling behaviors: A model approach with the theory of planned behavior. Western Anatolia Journal of Educational Sciences, http://webb.deu.edu.tr/baed/giris/baed/ozel_sayi/29-36.pdf (10.02.2015) 
Kışoğlu, M. ve Yıldırım, T. (2015). İlkokul ve ortaokullarda çevre eğitimi verecek olan öğretmen adaylarının katı atıklar ve geri dönüşüme yönelik tutumlarının farklı değişkenler açısından incelenmesi. International Journal of Human Sciences, 12(1), 1518-1536. doi: $10.14687 /$ ijhs.v12i1.3283

Tikka,P.M., Kuitunen, M.T., Tynys, S.M. (2000) Effects of educational background on students' attitudes, activity levels, and knowledge concerning the environment. The Journal of Environmental Education, 31(3), 12-19.

Timur, S., Yılmaz, Ş., Timur, B. (2013). İlköğretim öğretmen adaylarının çevreye yönelik tutumlarının belirlenmesi ve farklı değişkenlere göre incelenmesi. Abi Euran Üniversitesi Kirşehir Eğitim Fakültesi Dergisi (KEFAD), 14(2), 191-203.

Uzun, N., Sağlam, N. (2007). Ortaöğretim öğrencilerinin çevreye yönelik bilgi ve tutumlarına "Çevre ve İnsan" dersi ile gönüllü çevre kuruluşlarının etkisi. Hacettepe Üniversitesi Ĕgition Fakültesi Dergisi, 33, 210-218.

Yenice, N., Saracaloğlu, A.S., Karacaoğlu, Ö.C. (2008). The views of the classroom teacher candidates related to the environmental science course and the environmental sensibility. Asia-Pacific Forum on Science Learning and Teaching, Volume 9, Issue 1, Article 9.

Yılmaz, F., Gültekin, M. (2012). Sınıf öğretmeni adaylarının çevre sorunları bağlamında öğrenim gördükleri programa ilişkin görüşleri. Dicle Üniversitesi Ziya Gölkalp Eğitim Fakültesi Dergisi, 18, 120-132.

Yilmaz, O., Boone, W.J., Andersen, H.O. (2004). Views of elementary and middle school Turkish students toward environmental issues. International Journal of Science Education, 26:12, 15271546.

\section{Extended English abstract}

Environmental problems such as decrease of natural resources, water pollution, air pollution, global warming, thinning of ozone layer, decrease in bio-diversity and soil pollution are one of the crucial problems that humanity faces today. The problem of solid waste is also one of the issues that have become an important problem and that threatens the future of humanity. Solid wastes are pollutants that occur as a result of domestic, medical, industrial and agricultural human activities and that threaten human health. Today, there has been a growing interest in many countries in issues of protecting natural resources and struggle against environmental problems that are caused by the storage of solid wastes by traditional methods. Creating awareness on recycling is possible through gaining individuals the behaviour and habit of recycling. So, teachers who teach about environment and pre-service teachers who will teach about environment in the future should have positive attitudes towards solid wastes and recycling. Thus, the objective of this study is to examine the attitudes of pre-service teachers including science, primary school and social sciences teachers towards solid wastes and recycling and the effect of participants' gender, department, settlement, level of income, parents' educational status, membership to environmental associations and behaviour of separating the wastes and throwing them in recycle bins and preferring recycled products on the participants' attitudes.

The study is a descriptive research conducted by screening model. The sample of the study consists of 149 pre-service teachers at senior level in the departments of science, primary school and social sciences in the education faculty of a university located in Middle Anatolia region of Turkey. The reason why the sample consists of senior students is that senior-year preservice teachers have taken all courses in the department curriculum regarding environment and that they are going to start teaching soon. On the other hand, the reason why the sample is composed of science, primary school and social sciences pre-service teachers is that issues related to environment are involved in life sciences, science and social sciences curricula in 
Kışoğlu, M. ve Yıldırım, T. (2015). İlkokul ve ortaokullarda çevre eğitimi verecek olan öğretmen adaylarının katı atıklar ve geri dönüşüme yönelik tutumlarının farklı değişkenler açısından incelenmesi. International Journal of Human Sciences, 12(1), 1518-1536. doi: $10.14687 /$ ijhs.v12i1.3283

primary and secondary schools. The data of the study were collected through questionnaire method. The questionnaire used in the study comprises of two parts. The first part of the questionnaire involves questions that aim to determine the participants' gender, department, settlement, level of income, parents' educational status, membership to an environmental association, whether they separate their wastes and throw them into relevant recycling bin and whether they pay attention to if the product is suitable for recycling or not while they are shopping. The second part of the questionnaire involves the "Scale of Pre-service Teachers' Attitudes towards Solid Wastes and Recycling", which was developed by Karatekin (2013) and which consists of 33 items. The scale was developed to be Likert-5 and consists of three factors. As a result of the statistical analyses performed by Karatekin (2013) during the development of the scale, the reliability coefficient of the "initiation and participation" dimension was found out to be 0,892 , reliability of "belief" dimension was found out to be 0,882 and reliability of "interest and sensitivity" dimension was calculated as 0,877 .

It was revealed during the study that the average score of pre-service teachers on the scale of attitudes towards solid wastes and recycling is $\bar{X}=121,11$. When it is considered that the possible minimum score can be 33 and the possible maximum score is 165 , it can be said that the pre-service teachers have a positive attitude towards solid wastes and recycling. Besides, it was revealed that there is a statistically meaningful difference among the attitudes of pre-service teachers with regard to gender in all three dimensions of the scale $(p<, 05)$. Namely, the attitudes of female pre-service teachers towards solid wastes and recycling was higher than those of male pre-service teachers. It was found out that there was a meaningful difference among the scores on dimensions of the attitude scale with regard to department $(p<, 05)$. The attitude scores of science pre-service teachers are higher than scores of social sciences pre-service teachers on the initiation and participation dimension of the scale. Likewise, attitude scores of science preservice teachers are higher than scores of both primary school and social sciences pre-service teachers on the belief dimension of the scale. Attitude scores of science pre-service teachers are higher than scores of social sciences pre-service teachers, and scores of primary school preservice teachers are higher than scores of social sciences pre-service teachers on the interest and sensitivity dimension of the scale. Regarding the initiation and participation dimension of the scale, the attitude scores of those who throw their wastes after separating them are statistically higher than those who throw them without separating $(\mathrm{p}<, 05)$. On the belief dimension of the scale, there is no statistically meaningful difference between the attitude scores of those who throw their wastes after separating them and those who do not ( $p>, 05)$. It was found out that the attitude scores of those who throw their wastes after separating them are statistically higher than those who throw them without separating $(p<, 05)$. Regarding the initiation and participation dimension of the scale, the attitude scores of those who prefer recycled products are statistically higher than those who do not prefer recycled products $(\mathrm{p}<, 05)$. Furthermore, on the interest and sensitivity dimension of the scale, the attitude scores of those who prefer recycled products are statistically higher than those who do not prefer recycled products $(\mathrm{p}<, 05)$. On the other hand, on the belief dimension of the scale, there is no statistically meaningful difference between the attitude scores of those who prefer recycled products and those who do not ( $p>, 05)$. It was also revealed that there was no difference among the scores of the pre-service teachers who participated in the study regarding the scale of solid wastes and recycling in terms of settlement, level of income, parents' educational status and membership to an environmental association $(\mathrm{p}>, 05)$. 